\title{
BURIAL MOUND 7 OF SARA BURIAL GROUND (D.I. ZAKHAROV'S EXCAVATIONS, 1928): HISTORIOGRAPHIC RESEARCH ${ }^{1}$
}

\author{
Vitaliy K. Fedorov \\ R.G. Kuzeev Institute for Ethnological Studies - Subdivision of the Ufa Federal Research Centre, RAS, \\ Ufa, Russian Federation
}

\begin{abstract}
The article is devoted to historiographic research of the excavation materials from mound 7 of Sara burial ground. The excavations took place in the Eastern Orenburg area in 1928. The materials of these excavations entered scientific circulation in 1960 and contained serious errors, which greatly distorted the discoveries made there. B.F. Zhelezchikov, archaeologist from Volgograd, was the first to pay attention to this fact in 1997 but he just mentioned it briefly. We have conducted our own archival research and this article presents its results. The paper fully publishes the text of D.I. Zakharov's report, his plan of Sara burial ground, the plan and cross-section view of mound 7 excavated by him. The paper characterizes the photos of the finds attached to Zakharov's report as well. While comparing Zakharov's data with the information which entered scientific circulation in the middle of the previous century under the name of "mound 7 of the burial ground near the village of Sara" we identified "extra" artifacts included into the report accidentally. For example, an iron dagger, most arrowheads, all items of horse harness, a whetstone, a stone tile and some decorations were excluded from the finds supposedly made in this mound. The letter from director of Orenburg Museum I.A. Zaretskiy confirmed the earlier suggestions that these objects were found during grave robberies and accidentally included into the collection of finds from mound 7 of Sara burial ground. The paper publishes an excerpt from this letter. We restored the true picture of the excavations of 1928 and observed the burial rite of the burial in mound 7 - cremation at the side of the burial.

Key words: archaeological excavations of the beginning of the 20th century, archival research, restoration of the true picture of excavations, early nomads, burial rite, cremation, grave goods.
\end{abstract}

Citation. Fedorov V.K., 2019. Burial Mound 7 of Sara Burial Ground (D.I. Zakharov's Excavations, 1928): Historiographic Research. The Lower Volga Archaeological Bulletin, vol. 18, no. 1, pp. 149-164. (in Russian). DOI: https://doi.org/10.15688/nav.jvolsu.2019.1.12

\section{КУРГАН 7 МОГИЛЬНИКА САРА (РАСКОПКИ Д.И. ЗАХАРОВА 1928 г.): ИСТОРИОГРАФИЧЕСКОЕ ИССЛЕДОВАНИЕ ${ }^{1}$}

\footnotetext{
Виталий Кимович Федоров

Институт этнологических исследований имени Р.Г. Кузеева - обособленное структурное подразделение Уфимского федерального исследовательского центра РАН, г. Уфа, Российская Федерация

Аннотация. Статья посвящена историографическому исследованию материалов раскопок кургана 7 могильника Сара в Восточном Оренбуржье в 1928 году. Материалы этих раскопок были введены в научный оборот в 1960-х гг., с серьезными ошибками, сильно исказившими истинную картину сделанных там открытий. Впервые на это обратил внимание волгоградский археолог Б.Ф. Железчиков в 1997 г., но он ограничился
} 
лишь кратким упоминанием об этом. Нами проведены собственные архивные разыскания, результаты которых представлены в статье. Полностью публикуется текстовая часть отчета автора раскопок Д.И. Захарова и составленный им план могильника Сара, план и профиль раскопанного им кургана 7. Также охарактеризованы фотографии находок из этого кургана, приложенные к отчету Д.И. Захарова. Сопоставление данных Д.И. Захарова с комплексом сведений, вошедших в науку под наименованием «курган 7 могильника у села Сара» в середине прошлого века, позволило выявить «лишние» артефакты, включенные в него случайно. В частности, из числа находок якобы из этого кургана были исключены железный кинжал, большинство наконечников стрел, все предметы конской упряжи, оселок, каменная плитка, часть украшений. Выдвигавшееся ранее предположение о том, что эти предметы были найдены при грабительских раскопках и были случайно включены в коллекцию находок из кургана 7 Сары, находит подтверждение в письме директора Оренбургского музея И.А. Зарецкого, отрывок из которого публикуется. После восстановления истинной картины раскопок 1928 г. сделаны наблюдения над погребальным обрядом захоронения в кургане 7 - трупосожжением на стороне.

Ключевые слова: археологические раскопки начала XX в., архивные разыскания, реконструкция истинной картины раскопок, ранние кочевники, погребальный обряд, трупосожжение, погребальный инвентарь.

Цитирование. Федоров В. К., 2019. Курган 7 могильника Сара (раскопки Д.И. Захарова 1928 г.): историографическое исследование // Нижневолжский археологический вестник. Т. 18, № 1. С. 149-164. DOI: https://doi.org/ 10.15688/nav.jvolsu.2019.1.12

Материалы раскопок памятников ранних кочевников Южного Урала, проведенных в конце XIX - начале XX в. Ф.Д. Нефедовым, П.С. Назаровым, И.А. Кастанье, Д.И. Захаровым, И.А. Зарецким и другими исследователями, по сей день являются востребованными наукой, даже несмотря на то, что они были проведены по большей части неквалифицированно и уровень фиксации в них был весьма низок. Для археологов-«сарматчиков» позднейшего времени эти материалы стали как бы «привычными», и на них зачастую ссылаются так, как если бы с ними все было ясно. Между тем, если подвергнуть пристальному рассмотрению все сохранившиеся от этих ранних раскопок материалы, выявляются большие огрехи, сделанные при введении их в научный оборот. Так, О.Ф. Бытковский выяснил, что известный в археологии Южного Урала «курган Биш-Оба в окрестностях г. Орска» является на самом деле курганом 1 могильника Сара [Бытковский, 2016]. При подготовке к печати материалов раскопок могильника Сара, проведенных летом 1993 г., мы задались целью проверить все ранее публиковавшиеся сведения об этом могильнике, и его историографическая находка стала для нас полной неожиданностью. До сего дня мы пребывали в уверенности, что история исследования могильника Сара исчерпывается раскопками только одного кургана 7, проведенными в августе 1928 г. научным сотрудником Оренбургского музея Дмитрием Ивановичем
Захаровым. Причем картина его исследования была не вполне ясной - в литературе содержались противоречивые данные о составе сделанных там находок. Выяснению истинных результатов этих раскопок посвящена данная статья.

Уже в 1929 г. о раскопках Д.И. Дмитриева в Саре было упомянуто Паулем Pay: "Kurg. von Sara, Uralgebiet (zwischen Orenburg und Orsk; Brandhügel mit Resten mehrerer menschl. Körper und reichl. Inventar, Grabung Zacharov 1928), 55 bronzene und 48 eiserne Pfeilspitzen, Mus. Orenburg" 2 [Rau, 1929, s. 37]. Данным коротким сообщением сведения об этих раскопках исчерпывались в течение тридцати с лишним лет.

Впервые материалы кургана 7 Сары в более представительном виде стали известны из книг К.Ф. Смирнова. В «Вооружении савроматов» приведены рисунки железного кинжала с почковидным перекрестьем и антенным навершием, 137 бронзовых наконечников стрел, а также - не менее 50 железных наконечников, железных удил с псалиями, круглых железных распределителей ремней от конской сбруи [Смирнов, 1961, рис. 2,5,21A, 21Б, 22, 1-18, 45, 1, 46, 4, 50,1-4]. В своде «Савроматы Поволжья и Южного Приуралья» и «Савроматах» состав находок из Сары более обширный - помимо оружия и предметов конской упряжи, - зеркала нескольких типов, бусы также нескольких типов, керамический сосудик, железные ножи, ножны (?), оселок с от- 
верстием, каменная плитка, железный «умбон» или украшение колчана (?) с золотой инкрустацией, бронзовое колесико, золотая серьга с изображением горного козла, серебряная булавка, кожаный мешочек для благовоний и деревянной палочкой, деревянная скульптура головы лошади (?), покрытая рыжей шерстью [Смирнов, Петренко, 1963, табл. 18,15-17, $19,30,20,56,25,3,11,22,27,8,28,2,13,14$, 29,3,4,7; Смирнов, 1964, рис. 35А, 35Б]. В «Савроматах» впервые были приведены и сведения о погребальном обряде кургана 7 остатках коллективного трупосожжения, перекрытых берестой и нетолстыми стволами березы, расколотыми пополам [Смирнов, 1964, с. 86, 96]. План и профиль кургана до сего дня не публиковались.

Несовпадение между данными по наконечникам стрел, приведенными П. Рау и К.Ф. Смирновым, в тот момент не обратило на себя внимания. Понятие «могильник у села Сара» прочно закрепилось за тем комплексом сведений, который был опубликован К.Ф. Смирновым, на них последовали многочисленные ссылки в научной литературе.

Подозрения, что «с Сарой что-то не так», возникли при составлении базы данных по погребальному обряду памятников Азиатской Сарматии $^{3}$. В подготовленной Б.Ф. Железчиковым «Выверенной базе данных по погребальным памятникам савроматской эпохи» количество стрел в кургане 7 Сары совпадает с данными П. Рау, а не К.Ф. Смирнова, остальные предметы инвентаря также не имеют полного совпадения с опубликованными К.Ф. Смирновым. Было сделано следующее примечание: «Архивные изыскания показали, что к кургану, раскопанному Д.И. Захаровым, относятся только вещи, приведенные в базе. Остальные предметы были найдены при грабительских раскопках крестьян и происходят из других курганов этого же могильника» [Железчиков, 1997, с. 275, примеч. 10], при этом ссылка на архивные данные отсутствовала.

Таковы сведения о кургане 7 Сары, которые имеются на сегодняшний день в отечественной историографии. Они противоречивы и не ясны. Без обращения к сохранившимся архивным материалам составить представление об истинном положении дел с находками в кургане 7 Сары невозможно. От- чет Д.И. Захарова и другие сопутствующие ему документы хранятся в архиве ИИМК. Текстовая часть отчета очень короткая, и мы публикуем ее полностью.

\section{КРАТКИЙ ОТЧЕТ}

\section{По обследованию курганов \\ близ с. Сары (Петропавлов) \\ Оренбургского Округа \\ научным сотрудником \\ Оренбургского Окружного \\ Краеведческого Музея \\ ДМИТРИЕМ ИВАНОВИЧЕМ ЗАХАРОВЫМ ${ }^{4}$}

Согласно производственного плана я выехал в район с. Сары (Петропавловка) 1 августа 1928 года для выполнения заданий Оренбургского Окружного Краеведческого Музея. В числе других заданий на меня было возложено собрать данные о курганах, находящихся в районе указанного села, с производством разведки предварительного характера, а в случае необходимости и производства раскопок. Для выполнения этих заданий намечалось использовать от 6 до 8 дней.

Первой задачей я поставил себе нанесение всех обнаруженных курганов на карту (см. снимок).

Вся группа курганов в районе с. Сары, числом 18, расположена на возвышенности, идущей в направлении на север от с. Сары. Возвышенность эта опоясана линией Оренбург-Орской железной дороги и почти посередине прорезана долиной р. Чебоклы. Курганы расположены, главным образом, по наиболее возвышенной северной части Сырта около истоков р. Чебоклы, приблизительно в 2,5 километр. от них. Все курганы правильной формы, почти полушаровидные - высокие и приплюснутые - низкие.

13 курганов (№ 1, 2, 3, 4, 5, 6, 7, 8, 9, 10, 11, $17,18)$ образуют одну дугообразную цепь, расположенную концами на юг и разделенную небольшими от 40 до 60 м промежутками.

Цепь курганов почти по середине пересекается дорогой, идущей от с. Сары до выс. Н. Блява. От с. Сары до курганов этой группы около 7 километр. Курганы № 12, 13, 14 расположены в 6 верстах от с. Сары по доро- 
ге на хутор Харьковский, курган № 16 находится приблизительно в 11 километр. по дороге на хут. Воронежский и курган № 17 находится на расстоянии 14 килом. от с. Сары по дороге на хут. Линево.

Расположены курганы на ровной открытой местности степного характера. В 3-х километр. к югу от основной цепи курганов по течению р. Чебоклы и ее притоков имеются леса (чернолесье). В месте расположения курганов еще на памяти старожил находилось несколько крупных очень старых берез, теперь исчезнувших, а близ кургана № 5 и 6 имелся глубокий колодезь. Следов колодца мне установить не удалось. Насыпь курганов ничем не отличается от почвы прилегающей местности, и лишь в основной черноземной массе имеется в наличии галька, как результат смыва насыпного слоя кургана. Растительность ковыль на нетронутых местах курганов, сорняки на местах хищнических раскопок, обычные травы, растущие на перелогах, на вспаханных курганах. Никаких сооружений или остатков их на курганах и вблизи их не имеется. Основания курганов не имеют никаких ограждений или валов и лишь один из них (№ 6) опоясан теперь сильно засоренным, рвом около 0,5 метра глубиною и до 4,5 метров шириною. Весной здесь долго задерживается снеговая вода и тогда курганы оживляются массой пригоняемых сюда на водопой лошадей.

Курганы № 3, 4, 5 и 6 имеют крутые склоны при высоте в 4,5 метра и в поперечнике 25 метров, курганы № 9 и 12 высотою до 3 метров и в поперечнике 25-28 метров, курганы № 1, 2, 10, 11, 13, 16, 17 высотою от 0,7 до 1 метра и в поперечнике заметной возвышенной части 10-12 метров, № 7 высотою 1,9 метра и около 19 метров в поперечнике, № 14 - 2 метра, при поперечнике около 23 метров, № 15 и 16 высотою 2,6 метра, при поперечнике в 25 метров. Все высокие курганы имеют более крутые склоны, чем низкие, причем северный склон гораздо круче прочих.

Местные жители сообщали, что лет 3035 назад все курганы были раскопаны сыном местного землевладельца и все найденные вещи куда-то отправлены; они же говорили, что при раскопках были обнаружены массивные золотые украшения (браслеты) и много дру- гих ценных предметов. Хотя к сообщениям лиц из местного населения о разного рода ценных находках вообще нужно относиться с большой осторожностью, но наличие следов раскопок (ям с крутоспадающими стенками) на всех крупных курганах (№ 3, 4, 5, 6, 9, 12, 15, 16) говорит за то, что видимо раскопки были продуктивны и толкали на дальнейшие поиски.

С целью выявить, насколько продуктивны были хищнические раскопки, мною была углублена и расчищена $(2 \mathrm{~m} \times 2 \mathrm{~m})$ до основного грунта кургана одна из имеющихся ям размером до 4-х метров в поперечнике на вершине кургана (курган № 6). Работа началась с 12-го Августа. При этом оказалось, что по длине всего колодца почва перелопачена. На расстоянии 0,5 метра от линии почвы, покрывающей дно засыревшей ямы, обнаружены кости детского скелета, безусловно позднейшего происхождения (возможно брошен в яму в период голода 1921-22 года); по близости от костей скелета найдены две пуговицы белого стекла с четырьмя дырочками для пришивания и радиально расположенными рубчиками; пуговицы такого рисунка обычно употребляют в деревнях при шитье рубах. На глубине 3-х метров обнаружены лежащие в полном беспорядке почти разрушенные кости рук и ног взрослого человека и очень прочная, хорошо сохранившаяся часть темянной кости с очень толстыми стенками. Кроме этого никаких других предметов в почве, захваченной колодцем, не было обнаружено.

Потом я решил сделать пробный шурф в одном из маленьких курганов, т. к. вследствие распахивания на них не могло сохраниться следов от возможных раскопок. Взят был намеренно курган (№ 7), расположенный в непосредственной близости к наиболее крупному (№ 6) расхищенному кургану, и кроме того учтено то обстоятельство, что в сравнительно небольшой период времени этот курган может быть распашкой совершенно сравнен с окружающей местностью, то есть исчезнуть как исторический памятник. Колодец (шурф) был заложен посредине насыпи кургана. На глубине 1,6 метра обнаружилась покрышка погребения. Дальнейшая работа показала, что погребение не тронуто. По обнаружении в кургане погребения я решил, в силу уже высказанных мною соображений, приступить к 
вскрытию его. Работа началась с 16 Августа и была закончена 20-го Августа. По снятию насыпного слоя, обнаружилась берестяная покрышка (таб. VII) всего погребения площадью около 10 кв. метров, эллипсовидной формы, с C-CB направлением оси. Покрышка, по вскрытии ее, оказалась не из чистой бересты, а из коры с берестой и даже местами из не толстых стволов березы, покрытых корою, и расколотых пополам; вся покрышка была настлана в несколько рядов, спрессовавшихся под давлением насыпного слоя. Под слоем покрышки оказалась зола, но почти без угля. Частицы угля, очень измельченные, были разсеяны во всей массе золы и только в одном месте (крайний $\mathrm{C}-\mathrm{CB}$ конец оси погребения) обнаружено около полной пригоршни крупных углей; но угли лежали несколько выше древесной покрышки. Вблизи их находилось несколько костей - кости ноги и часть челюсти лошади, мелкие кости скелета барана и грудная кость небольшой птицы (куропатки). Масса золы рыхла, совершенно суха; в верхнем слое ее были размещены разные предметы, а в массе пепла человеческие кости на $\mathrm{C}-\mathrm{C}-\mathrm{B}$ конце куски кости черепа (№ 1 таб. II), несколько зубов старого (?) человека, и на противоположном Ю-Ю-3 конце зубы (№ 19 и 21) более сохранившиеся; вблизи этих последних находились части тазовых костей (видимо женских). Тазовые кости быстро на воздухе разрушились. Расположение остальных предметов указано на прилагаемом снимке. При этом мое внимание останавливалось на следующем. Стрелы были размещены концами в одну сторону, в восточном направлении; древков стрел не обнаружено даже в виде сгнившей массы, а почти в каждом наконечнике остался только конец древка от 1 до 2 сантимет. длиной. Видимо мы в данном случае имеем лишь обломанные наконечники стрел. Вместе со стрелами здесь же оказались истлевшие куски кожи. Один кусок кожи более других сохранившийся (№ 2 таб. VII) имеет три стрелы, приставшие (довольно прочно) к коже с той и другой стороны. Самое направление стрелок дает основанием утверждать, что наконечники стрел не имели полных длинных древков. Расположение наконечников стрел по ту и другую сторону, характер изгибов кожи (смятая) дает основание предполагать, что здесь мы имеем не колчан, а простой кусок кожи (бараньей?), в который были завернуты обломанные наконечники стрел. Обследование концов древков стрел установило, что часть древков сделаны из кусков круглого дерева путем расщепки и соскабливания, а несколько [пропуск] сделаны из прутиков, с ясно заметной в середине оставшихся частей древка сердцевиной. В бронзовых стрелах мной мною выявлено 11 разновидностей по несколько экземпляров и лишь один наконечник листовидный. Вместе с бронзовыми стрелами были помещены и железные, все окислившиеся, часть их «спеклась» с бронзовыми стрелами (см. № 4 и последние в первом ряду № 2 таблица III). Наличие других стрел в погребении может указывать, отчасти, на переходную в то время стадию от бронзовых изделий к железным, а также и на устойчивость употребления бронзовых стрел, как наиболее легких для изготовления. Длина наконечников бронзовых стрел от 2,2 до 5,5 сант. и железных (по частичном разрушении их) от 2 до 4 сант. Все наконечники надевались на конец древка, привязей не обнаружено. Бронзовых стрел 55 штук, а железных отдельных - 48 штук, и в 4 спекшихся кусках - 12 штук. В том же самом месте, где помещались стрелы, непосредственно над ними, были размещены, видимо, в (кожаном?) сосуде, от которого осталось несколько небольших кусочков (№ 26 табл. VII), семена какого-то мотылькового (?) растения. Зерна около 0,2 см. в поперечнике (№ 3 - табл. VII). Мысль, что это может быть содержимое запасов кого-либо из грызунов, отпадает, во-первых, потому, что кроме этих зерен никаких других предметов в этом месте не обнаружено (что обычно наблюдается в норах грызунов), а во-вторых, семена растения были положены под самой настилкой над слоем пепла и часть этих зерен вдавилась в кору березы (настилки). Кусочек березы со вдавленными в кору семенами помещен в пробирку (№ 3) вместе с частью взятых из погребения семян.

Обратил я внимание и на нахождение в погребении одновременно горшечка (№ 10), сделанного без помощи гончарного круга и 5ти небольших черепочков тонкой, по окраски и материалу римской (?), работы на кругу (№ $116^{5}$ таб. V). В горшечке (№ 10 таб. V), 
заткнутом пробкой, сделанной из ствола березы, подходящего диаметра (с корой), находилось затвердевшее смолистое вещество желтоватого цвета, горящее сильным пламенем и ароматное (запах горящего янтаря) (см. пробирку под № 10, таб. V).

В группе из зеркала, раковины и роговых пластинок (№ 5, таб. VI, № 6, 7 табл. V) находился предмет (№ 8 таб. 7), представляющий кусок мягкой (сохранившей эластичность до данного момента) кожи с насыпанным в середине его порошком черного цвета; затем края куска, видимо, были соединены и перетянуты ниткой, скрученной из жилы; стянуты концы куска неплотно, а оставлено маленькое отверстие, в которое вставлена остроганная палочка. Таким образом из куска кожи получился своеобразный кожаный пузырек с пробкой. Порошок при прокалке издает приятный запах. Возможно, что это какой-либо косметический препарат, на что может намекать и нахождение его в соседстве с зеркалом. Зеркал обнаружено 6, разной величины; из них три (№ 14, 17, 24, табл. VI) имеют загнутые края (подобный загиб мы наблюдаем у сковороды); размер зеркал - № 14 - Д = 13,8 сант.; № 17 Д = 24 ст. № $24-$ Д $=15,5$ сант. Зеркала под номерами 15, 11, 23 (табл. VI) - плоские; размер № 5 - одна ось 16 сант., другая 15 с., № 11 - 11 и 10 сант., № 23 - 7,5 и 6 сант.

Я обратил внимание, что два зеркала имели сломанные когда-то ручки, и к ним были приделаны - к зеркалу № 11 роговая орнаментированная ручка, а к другому под № 17 тоже орнаментированная костяная ручка. Ручка у зеркала № $14^{6}$, видимо с разрезом на конце, была прикреплена с помощью деревянных клинушков, а у № 17 с помощью железных заклепок. Зеркало № 5 (хорошо сохранившееся) имело рукоятку, обернутую кожей (сохранился на ручке кусок кожи), перевитой ниткой из двух скрученных прядок (см. № 5 около ручки).

Количество обнаруженных в погребении зубов [пропуск] штук наводит на мысль о коллективном погребении.

Несколько странным представляется мне нахождение единственной части челюсти с сохранившимися резцами, клыком и коренными зубами (№ 18, табл. VII) на большом зеркале № 17 (таб. VI). Кость приобрела ярко-зеленую окраску, видимо, от солей меди.
Не могло не обратить на себя внимание и нахождение в погребении куска гончарной (?) глины, смятой в виде продолговатого бруска. (Кусок распался на 4 части) и отдельного небольшого куска такой же глины, имеющего шарообразную форму (№ 25 таб. VI). Назначение этих кусков при погребении для меня представляется очень неясным. К числу таких же предметов неизвестного назначения нужно отнести две раковины № 7 и 13 таб. V, кусочек серы № 12 таб. VI и кусок дерева (№ 4, таб. VII), покрытый волосами. Кусок серы был, видимо, довольно солидных размеров, но большая часть его обратилась в очень тонкий порошок, и остался лишь небольшой кусочек около 1 куб. сант.

Кусок дерева имеет по длинной оси 11,2 сант. и 6 сант. по короткой. Кусок обделан каким-то режущим орудием, имеет форму лошадиной (?) головы. Покрыт волосами в направлении от толстого конца к тонкому. Возможно, что этот кусок, учитывая его сходство по форме с лошадиной головой, помещен в погребение вместо настоящей лошади, обычно находимой при раскопках могильных курганов.

Из украшений в погребении обнаружены бусы разных размеров - мастиковых круглых $(0,4$ сант. в поперечнике) - 4 штуки, круглых приплюснутых $(0,8$ сант. в поперечнике) - 12 штук, стеклянная продолговатая $(1,8 \times 0,8 \times 0,8)-$ одна, одна тоже стеклянная, но трехугольная бородавчатая $(1,2$ сант. в поперечнике и 0,8 сант. толщины) и одно шейное бронзовое украшение (?) № 15 в виде кружка с 6 отверстиями, одно из них в центре и 5 по желобку, который отделяет утолщенный наружный край кружка.

Несомненно, что специалист о многом заставил бы рассказать нам это погребение и дал возможно-исчерпывающие объяснения как нахождению в погребении некоторых предметов, так и самой обстановке погребения, напр. отсутствию в погребении углей при наличии большого количества золы.

ПРИЛОЖЕНИЯ:

№ 1 - Схематический план группы курганов вблизи с. Сара, план погребения кургана № 7, разрез его.

№ 2 - Снимок предметов погребения: кости черепа, зубы, осколки бус, зубы, часть черепа. 
№ 3 - Снимок предметов погребения: наконечники стрел (бронзовые), остатки древков, бронзовые и железные наконечники («спекшиеся»).

№ 4 - Снимок предметов погребения: стрелы (наконечники) железные и куски «спекшихся» железных наконечников.

№ 5 - Снимок предметов погребения: бусы, куски роговых пластинок, раковины, два железных предмета, горшочек и под ним масса из него, осколки сосуда, шейное украшение.

№ 6 - Снимок предметов погребения: зеркала при № 5, кусочек кожи с ручки от зеркала и нитка из жилы, кусочек серы, куски глины.

№ 7 - Снимок предметов погребения берестовая покрышка, мешочек из кожи с пробкой, семена растений, кусок кожи с прилипшими к нему наконечниками стрел, кусок дерева, покрытый волосами, кусочки полусгнившей кожи, а под ними (№ 13б) морские раковины.

\section{НАУЧНЫЙ СОТРУДНИК ОКРМУЗЕЯ под-} пись (ЗАХАРОВ) [Захаров, 1929].

Иллюстрации к отчету Д.И. Захарова из архива ИИМК (называемые в отчете «таблицами») представляют собой фотографии, наклеенные на картонки. Качество их невысокое, они недостаточно резкие, тон коричневатый.

Таблица № 1 - это фотография листа бумаги, на котором изображены план группы курганов (рис. 1), план погребения и разрез кургана, с пояснениями к ним. Помещенный на ней «План погребения» представляет собой овал, усеянный черными кружочками с номерами от 1 до 27, каждый из которых показывает местонахождение той или иной находки (рис. 2), поименованной в «Экспликации к плану погребения», помещенной тут же слева.

Таблицы № 2-7 - это фотографии планшетов, к которым гвоздями прибиты листы картона (?) с зафиксированными на них предметами.

\section{Сопоставление данных}

\section{Д.И. Захарова и К.Ф. Смирнова}

Текст отчета Д.И. Захарова, план погребения с экспликацией и таблицы с фотографиями находок позволяют установить с большой степенью достоверности, какие же имен- но находки были сделаны в кургане 7, а какие не были.

Предметы вооружения. Сведения о находке кинжала (рис. 5,1) в данных Д.И. Захарова отсутствуют. С наконечниками стрел сложнее - идентификация их затруднена однотипностью материала и невысоким качеством фотографий, приложенных к отчету Д.И. Захарова. Спасают положение принадлежность некоторых из наконечников к редким разновидностям и характерные индивидуальные особенности, например, отсутствие у одного кончика жала. В «Савроматах» к стрелам, действительно найденным Д.И. Захаровым, безусловно, можно отнести из бронзовых - один двухлопастной наконечник стрелы, два трехлопастных с выступающей втулкой, и два трехгранных с внутренней втулкой, а также все железные [Смирнов, 1964, рис. $35 \mathrm{~A}, 46$ (слева), $4 \kappa, 4 o, 4 \phi$ (по обе стороны буквы «ф»), 35Б, 2] (рис. 3,I). Из остальных бронзовых наконечников некоторые могут происходить из кургана 7 , но точная их идентификация не возможна (рис. 3,II). Можно лишь утверждать, что известный наконечник стрелы с изображением лука на одной из лопастей, второй двухлопастной наконечник стрелы, крупный трехлопастной с подромбической головкой, пулевидный и оба черешковых в кургане 7 Сары найдены не были [Смирнов, 1964, рис. 35А, $4 a, 46$ (справа), 46, 4u, 35Б, 1] (рис. 3,III).

Принадлежности конской узды. Железные распределители ремней и две пары удил [Смирнов, 1964, рис. 35A,3,5,10] в материалах Д.И. Захарова не значатся, и, следовательно, не были найдены в кургане (рис. 5,9-11).

Зеркала. Здесь мы наблюдаем совпадение данных К.Ф. Смирнова с данными Д.И. Захарова. Оба пишут о 6 зеркалах, полностью совпадают и их изображения (рис. 4,1-б).

Украшения. У Д.И. Захарова не упоминаются золотая серьга с изображением горного козла и серебряная булавка [Смирнов, 1964, рис. 35Б,9,12] (рис. 5,5,7). Из украшений в отчете есть данные только о бусах (рис. 4,9). На плане раскопа они показаны в северной части рядом с костями черепа и зубами, что заставляет предположить неслучайное расположение находок. Еще два скопления показаны в южной части раскопа. Приве- 
дем описание бус из отчета: «Из украшений в погребении обнаружены бусы разных размеров - мастиковых круглых $(0,4$ сант. в поперечнике) - 4 штуки, круглых приплюснутых ( 0,8 сант. в поперечнике) - 12 штук, стеклянная продолговатая $(1,8 \times 0,8 \times 0,8)-$ одна, одна тоже стеклянная, но трехугольная бородавчатая $(1,2$ сант. в поперечнике и 0,8 сант. толщины)». Всего упомянуты 18 бусин, но на «Таб. V» изображены 19 бусин, одна крупная шарообразная в тексте не упоминается.

Среди бус обращает на себя внимание эллипсоидная бусина со светлыми поперечными полосами. Очевидно, именно ее Д.И. Захаров называет «стеклянной продолговатой», хотя она, без сомнения, каменная. В своде К.Ф. Смирнова и В.Г. Петренко она названа «сардониксовой (?)» [Смирнов, Петренко, 1963, с. 32, табл. 27,8]. Из других бус у К.Ф. Смирнова имеются только круглые, круглые приплюснутые и две бисеринки - круглая и вытянутая (последние у Д.И. Захарова не упоминаются).

В отчете Д.И. Захарова есть данные о нескольких бусинах, отсутствующих у К.Ф. Смирнова. На «Таб. ІІ» помещено три обломка бус, не имеющие особого номера, слева под кусками черепа. По меньшей мере один из них (средний) принадлежит бусине с сосцевидными налепами. Может быть, это бусы, найденные в северной части. Подобная бусина представлена и на «Таб. V» («трехугольная бородавчатая»).

Прочие предметьл. В отчете Д.Т. Захарова нет данных о цельнометаллическом ноже с ножнами (?), составленными из железных обойм, каменном оселке, каменной овальной плитке и железном, украшенном золотом «умбоне» [Смирнов, 1964, рис. 35А, 2,3,6,9] (рис. 5,2-4,6,8). Согласно отчету найдены были 2 неопределенных железных предмета, бронзовое колесико, сосудик, поделка из дерева и кожаный мешочек с торчащей из него палочкой [Смирнов, 1964, рис. 35А, 7,8, 35Б,4,6,13,15] (рис. 4,7,8,10-13).

\section{О возможных причинах несоответствия}

\section{данных Д.И. Захарова и К.Ф. Смирнова}

В каком состоянии находилась коллекция предметов из Сары в то время, когда с нею работал К.Ф. Смирнов, неизвестно.
О том, что он внимательно изучил отчет Д.И. Захарова, говорят прямые цитаты из него в «Савроматах». Каким же образом возникла путаница и в коллекции предметов из кургана 7 Сары оказались «лишние»? Очевидно, мы этого уже не узнаем, но сделать одно предположение можно.

Копия письма «В Главнауку» директора Оренбургского музея И.А. Зарецкого от 29 июня 1929 г., хранящаяся вместе с отчетом Д.Т. Захарова в архиве ИИМК, позволяют выдвинуть предположение. Мы приведем лишь ту его часть, которая (может быть) имеет отношение к материалам курганов Сары.

«Музей заявляет, - пишет И.А. Зарецкий, - что в Оренбургском Округе во многих местах производятся организованные хищнические раскопки с ведома местных властей, причем обнаружены находки чрезвычайной научной и материальной ценности и они большею частью уже погибли для науки. Поэтому Музей считает неотложной необходимостью произвести раскопки тех курганов, которые еще уцелели пока рядом с расхищенными.

Хищнические раскопки сейчас ведутся в Илекском районе в с. Покровке, в Шарлыкском районе в с. Прохоровке, где и раньше крестьяне самовольно производили раскопки курганов, и оттуда в Музее имеется часть предметов большой научной ценности. В начале июня с.г. Музеем были получены сведения, что в Орском районе производятся хищнические раскопки курганов крестьянами; на место раскопок был командирован научный сотрудник ОкрМузея Зарецкий, которому удалось отобрать несколько ценных предметов древности, сохранившихся на руках раскопщиков, однако большая часть растеряна и безвозвратно погибла» [Зарецкий, 1929].

Можно предположить, что в музей Зарецким были доставлены вещи, отобранные в том числе и у грабителей курганов в Саре. И, может быть, они были присоединены к «саринской» коллекции.

\section{Погребальный обряд кургана 7 могильника Сара, некоторые современные наблюдения}

Сразу оговорим, что имеющиеся материалы не дают ответа на целый ряд важных 
вопросов. Из Отчета Д.И. Захарова даже нельзя установить, какую площадь он вскрыл на кургане. Свой раскоп он называет «пробным шурфом», «колодцем», площадь погребального сооружения оценивает в 10 кв. м, но разрез кургана на «Табл. І» показывает его вскрытым целиком. Истинная картина раскопок Захарова остается неизвестной. Каков в действительности был погребальный обряд, сколько человек было погребено, почему из их костей найдены только фрагменты черепов и зубы, почему предметы погребального инвентаря не тронуты огнем? На все эти вопросы ответов тоже нет. Тем не менее оставить изученные материалы совсем без комментария мы не можем и выскажем некоторые наши соображения.

Д.И. Захаров затруднился реконструировать «обстановку погребения», о чем прямо говорит в последней фразе своего отчета: «Несомненно, что специалист о многом заставил бы рассказать нам это погребение и дал возможно-исчерпывающие объяснения как нахождению в погребении некоторых предметов, так и самой обстановке погребения, например отсутствию в погребении углей при наличии большого количества золы».

Первым специалистом, высказавшим свое мнение о погребальном обряде данного кургана, был П. Рау, определивший его как «погребальное сожжение с многочисленными человеческими телами и богатым инвентарем» (Brandhügel mit Resten mehrerer menschl. Körper und reichl. Inventar, см. выше). Сожжение, несомненно, имело место, но где именно оно происходило все же остается не ясным - было ли оно устроено непосредственно на погребальной площадке, или совершено на стороне и под насыпью были размещены лишь взятые с места сожжения зола и кости? Несомненно одно - погребальный инвентарь не находился в момент сожжения вместе с человеческими телами. К.Ф. Смирнов полагал, что сожжение происходило на месте погребения, а инвентарь положили на «остатки уже потухшего костра», закрыли деревянным «покрытием» и засыпали землей [Смирнов, 1964, с. 99].

Наиболее заметным свидетельством трупосожжения на древнем горизонте является не столько наличие золы и углей, сколь- ко прокал. «В ряде случаев огонь бушевал с такой высокой температурой, что полностью сгорали и деревянная конструкция, и тело погребенного в ней человека, а насыпь прокаливалась докрасна на несколько десятков сантиметров» [Ульянов, 2002, с. 15]. В наших раскопках кургана 4 Сосновки с сожжением деревянного сооружения, устроенного на древнем горизонте [Васильев, Савельев, Федоров, 1995, с. 68-69, рис. 7], ярко-красный прокаленный грунт обратил на себя внимание почти сразу под пахотным слоем. О прокале в кургане 7 Сары Д.И. Захаров не упоминает.

По-видимому, все же обряд реконструируется следующим образом: сожжение погребенных происходило на стороне, остатки погребального костра - зола с костями людей были размещены на погребальной площадке кургана, сверху на них был положен погребальный инвентарь, а затем все это перекрыто сверху берестой с жердями и плахами и возведена земляная насыпь. Но точно определить «обстановку погребения» могут помочь лишь повторные раскопки кургана 7.

\section{ПРИМЕЧАНИЯ}

${ }^{1}$ Работа выполнена в рамках НИОКТР № АААА-А19-119042300139-1 «Музей археологии и этнографии: коллекционные ресурсы, исследовательская деятельность и новые информационные технологии».

The work was carried out within Research and Development Project no. AAAA-A19-119042300139-1 "Museum of Archaeology and Ethnography: Collection Resources, Research Activities and New Information Technologies" state task.

${ }^{2}$ Курган у Сары, уральского региона (между Оренбургом и Орском; погребальное сожжение с многочисленными человеческими телами и богатым инвентарем, раскопки Захарова 1928), 55 бронзовых и 48 железных наконечников стрел, Музей Оренбурга.

3 Этот огромный труд был предпринят по инициативе М.Г. Мошковой, осуществлен под ее научным руководством и с ее непосредственным участием.

\footnotetext{
${ }^{4}$ Орфография сохранена.

${ }^{5}$ На таблице V -116.

${ }^{6}$ Ошибка, речь идет о зеркале № 11, зеркало
} № 14, судя по фото, - цельнометаллическое. 


\section{ИЛЛЮСТРАЦИИ}

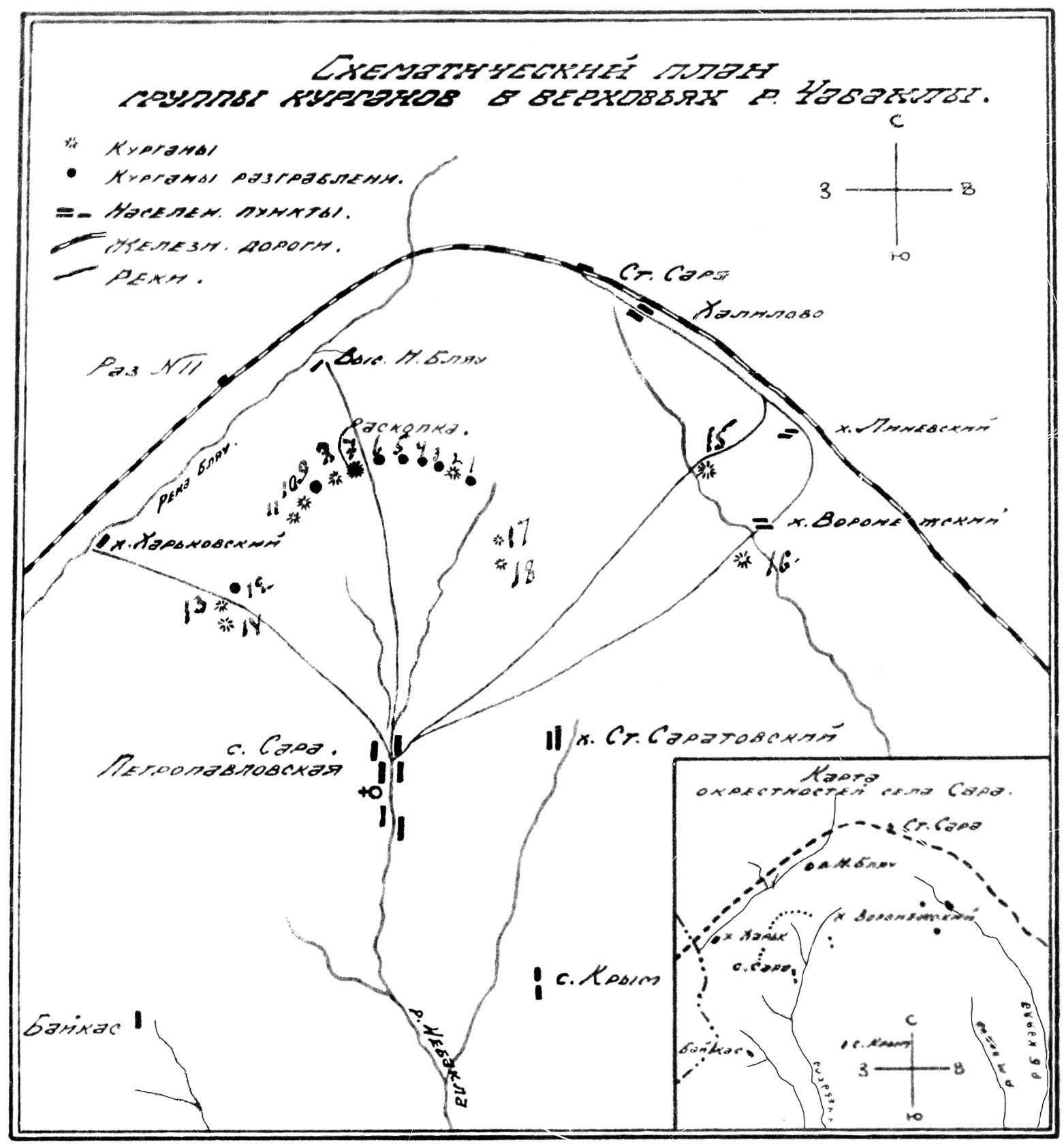

Рис. 1. Схематический план группы курганов в верховьях р. Чабаклы (по: [Захаров, 1929, табл. I])

Fig. 1. Schematic plan of the mound group in the upper flow of the Chabakly River (after: [Zakharov, 1929, tabl. I]) 


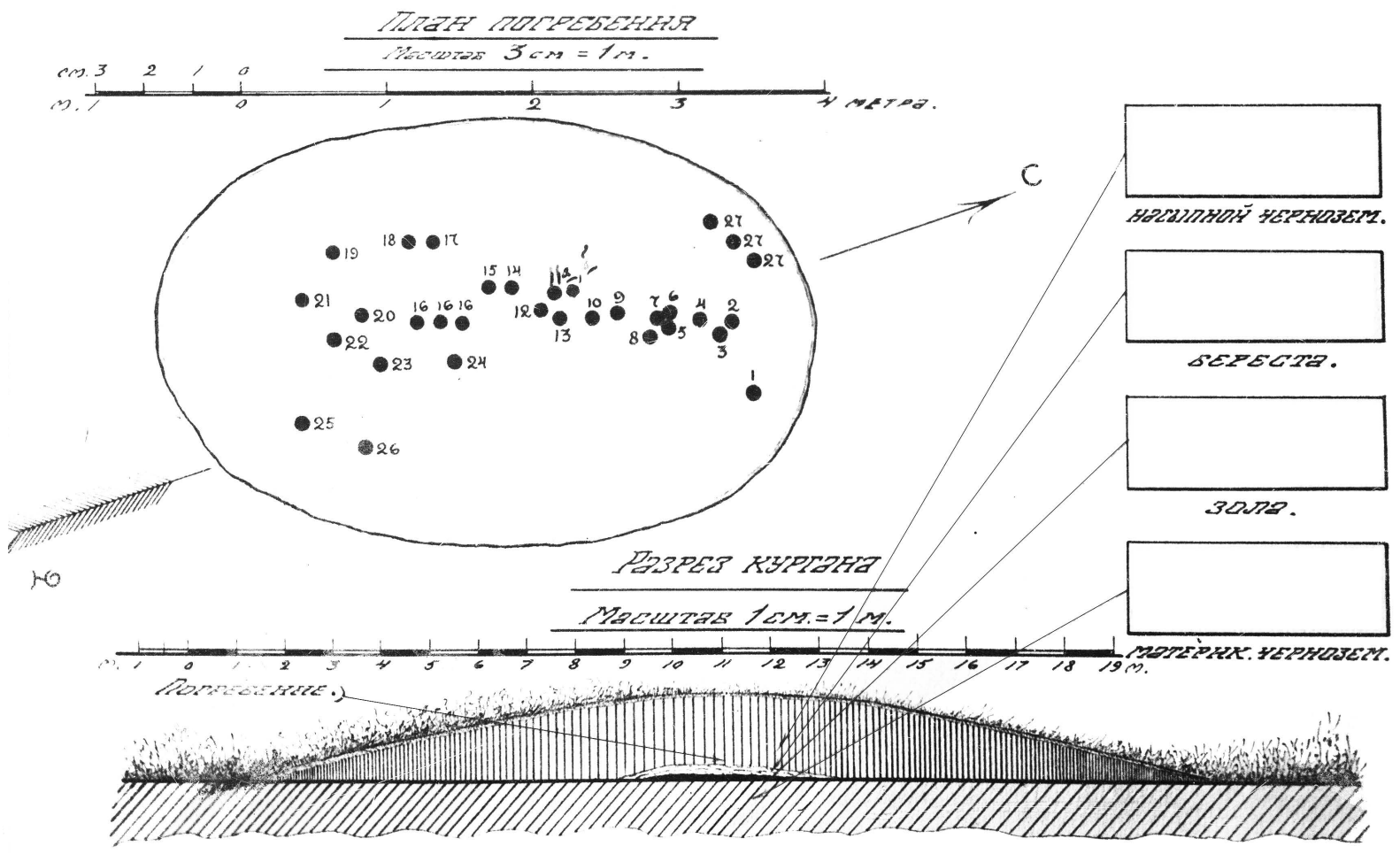

Рис. 2. План погребения в кургане 7 могильника Сара, перечень находок согласно экспликации к плану. Разрез кургана (по: [Захаров, 1929, табл. I]):

1 - кости черепа, 2 зуба и 3 осколка бусин; 2 - стрелы (бронзовые и железные), куски кожи; 3 - бобовые культуры; 4 - кусок дерева с волосами; 5 - зеркало; 6 - роговая пластинка; 7 - раковина; 8 - кожаный мешочек;

9 - три железных предмета неизвестного назначения; 10 - горшочек с массой; $11 a$ - зеркало; 116 - пять черепков; 12 - кусок серы и раковина; 13 - раковины; 14 - зеркало; 15 - шейное украшение;

16 - человеческие кости (таза и ног); 17 - большое зеркало; 18 - часть челюсти; 19 - зубы; 20 - бусы; 21 - зубы; 22 - бусы; 23 - зеркало; 24 - зеркало; 25 - четыре куска глины; 26 - зубы; 27 - часть костей скелета лошади (череп и задняя нога)

Fig. 2. Plan of the burial in mound 7 of Sara burial ground, list of finds according to the explication to the plan. Cross-section view of the mound (after: [Zakharov, 1929, tabl. I]):

1 - skull bones, 2 teeth, 3 shards of beads; 2 - arrows (bronze and iron), parts of leather; 3 - legumes; 4 - piece of wood with hair; 5 - mirror; 6 - horn plate; 7 - shell; 8 - leather pouch;

9 - three iron items of unknown purpose; 10 - pot with some substance; $11 a$ - mirror; 116 - five fragments of vessels; 12 - piece of sulfur and a shell; 13 - shells; 14 - mirror; 15 - neck decoration;

16 - human bones (pelvis and legs); 17 - big mirror; 18 - part of a jaw; 19 - teeth; 20 - beads; 21 - teeth; 22 - beads; 23 - mirror; 24 - mirror; 25 - four lumps of clay; 26 - teeth; 27 - parts of a horse skeleton (a skull and a hind leg) 

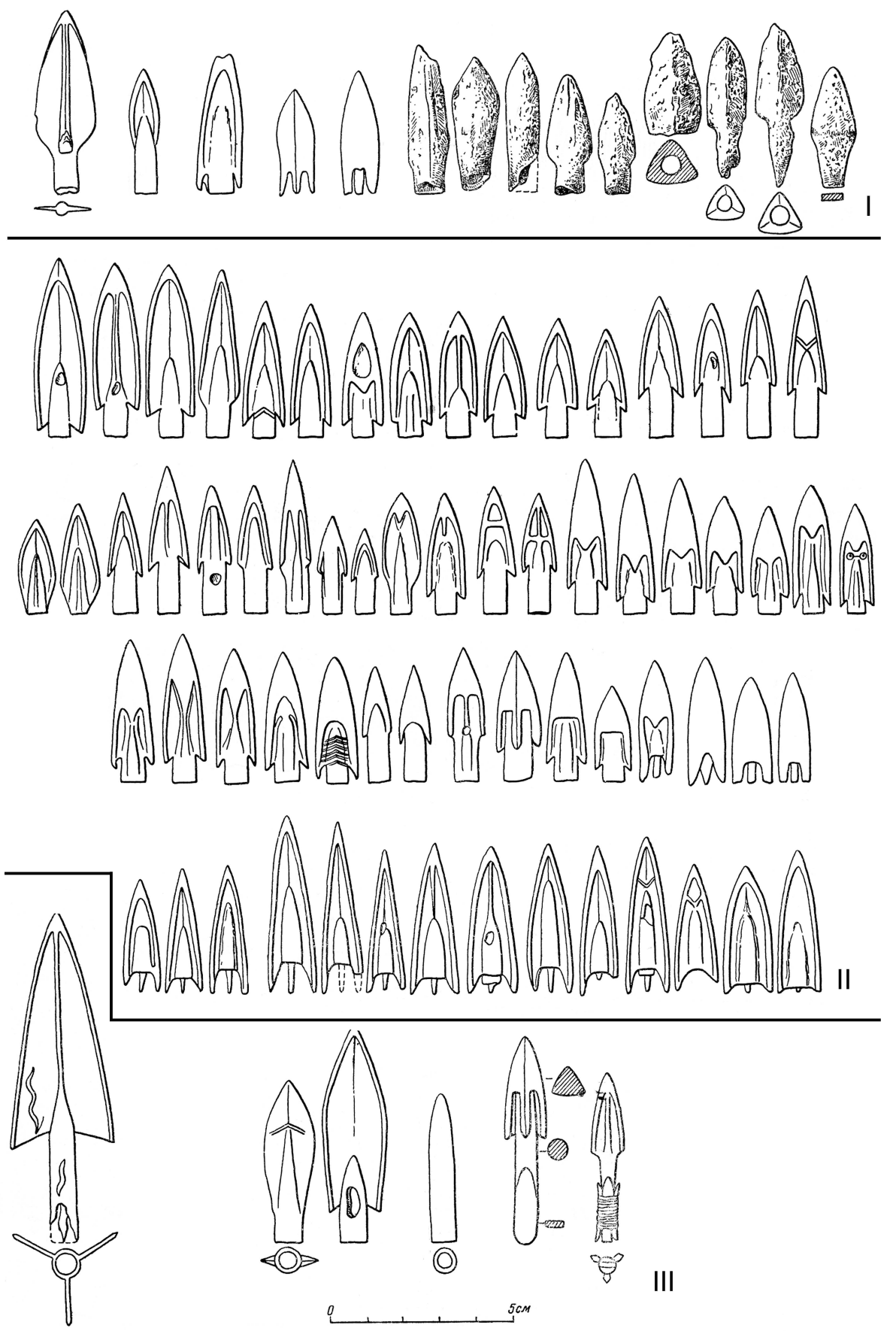

Рис. 3. Наконечники стрел (по: [Смирнов, 1964, рис. 35А,4, 35Б, 1,2]):

$I$ - наконечники, которые с большой долей вероятности идентифицируются с представленными на фотографиях (табл. III и IV) из отчета Д.И. Захарова (бронзовые и железные);

II - наконечники, которые не удается точно идентифицировать с представленными на фотографии (табл. IV)

из отчета Д.И. Захарова, но некоторые из них могут происходить из его раскопок;

III - наконечники, которые безусловно отсутствуют на фотографии (табл. IV) из отчета Д.И. Захарова

Fig. 3. Arrowheads (after: [Smirnov, 1964, fig. 35A,4, 35Б,1,2]):

$I$ - arrowheads that are very likely identified with those shown in the photos (tables III, IV) from D.I. Zakharov's report (bronze and iron);

II - arrowheads which cannot be accurately identified with those shown in the photos (table IV)

from D.I. Zakharov's report but some of them could be unearthed during his excavations;

$I I I$ - arrowheads which are definitely missing in the photo (table IV) from D.I. Zakharov's report 


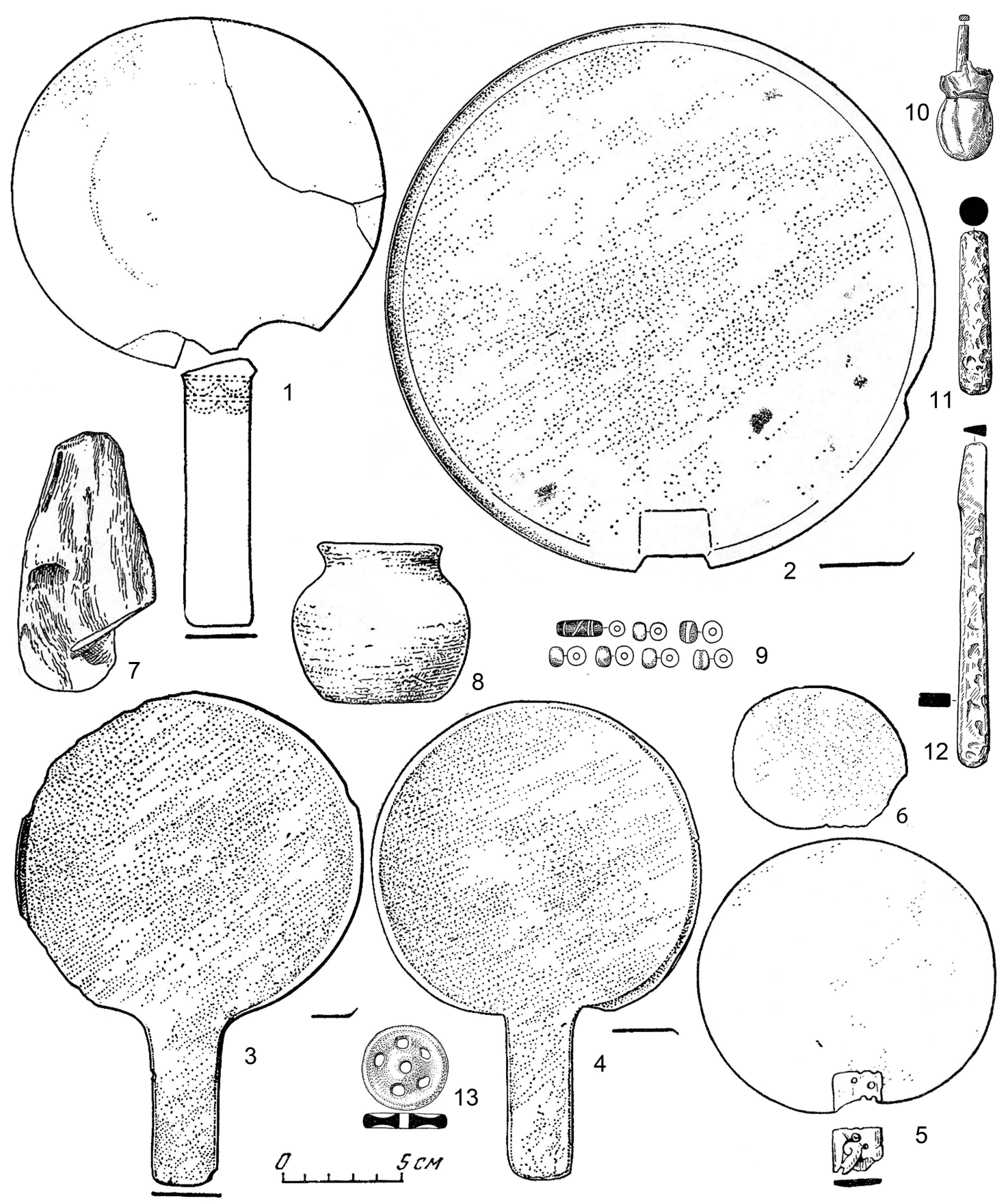

Рис. 4. Предметы из кургана 7 могильника Сара, находки которых подтверждаются текстом отчета Д.И. Захарова и иллюстрациями к нему (по: [Смирнов, 1964, рис. 35А, 7, 8, рис. 35Б, 4, 6-8, 11, 13-16; Смирнов, Петренко, 1963, табл. 28,14]):

1-6 - бронзовые зеркала; 7 - кусок дерева в виде головы лошади; 8 - глиняный сосудик с желтым веществом; 9 - бусины; 10 - кожаный флакончик для благовоний и деревянная палочка; 11-12 - железные предметы; 13 - бронзовое колесико

Fig. 4. Items from mound 7 of Sara burial ground, the finds of which are confirmed by the text of D.I. Zakharov's report and illustrations to it (after: [Smirnov, 1964, fig. 35A, 7, 8, fig. 35Б, 4, 6-8, 11, 13-16; Smirnov, Petrenko, 1963, tabl. 28,14]):

1-6 - bronze mirrors; 7 - a piece of wood in the shape of a horse head; 8 - small clay vessel with some yellow substance; 9 - beads; 10 - small leather incense bottle and a wooden stick; $11-12$ - iron items; 13 - small bronze wheel 


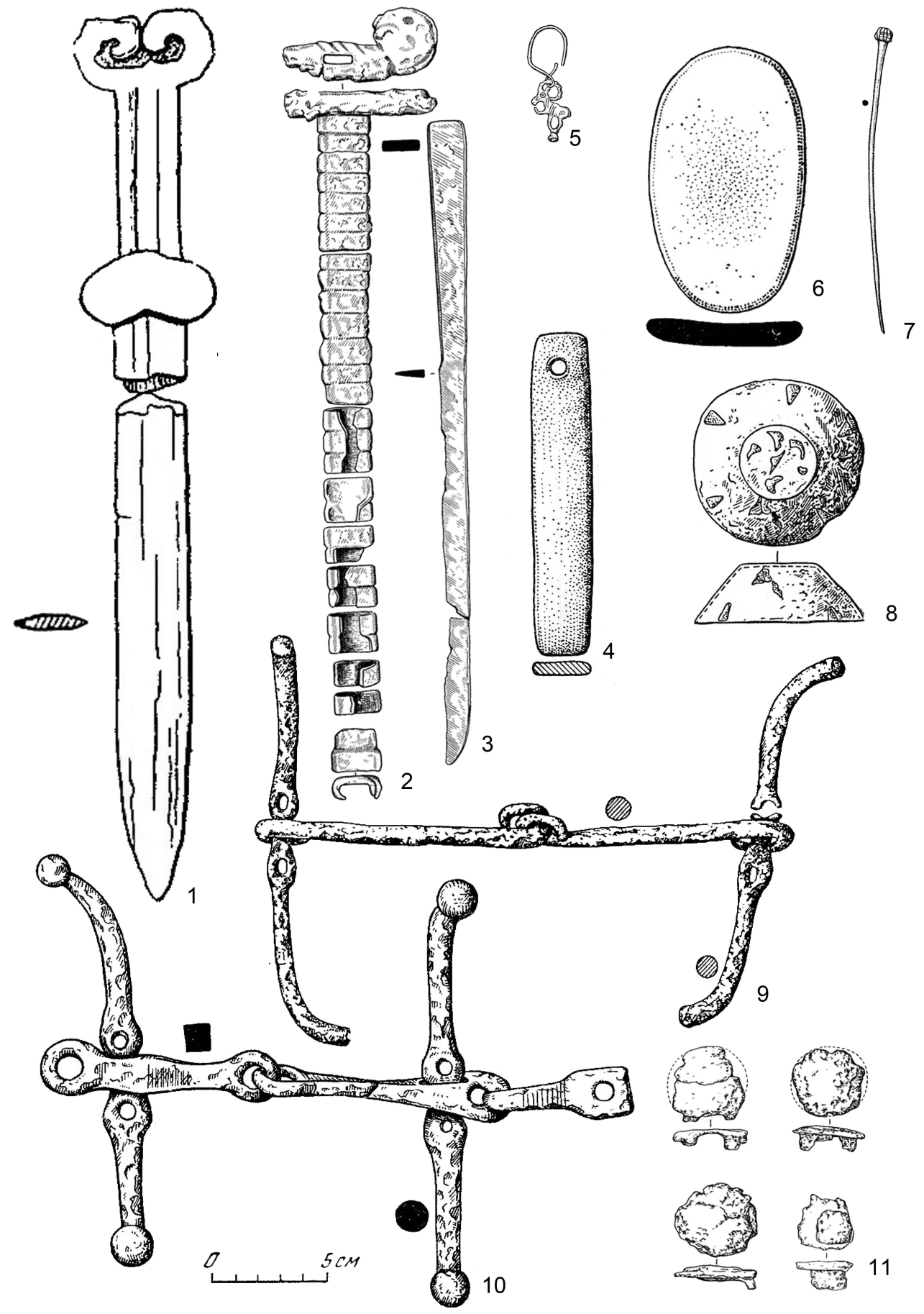

Рис. 5. Предметы, находки которых в кургане 7 могильника Сара не подтверждаются текстом отчета Д.И. Захарова и иллюстрациями к нему (по: [Смирнов, 1964, рис. 35А, 1-3, 5, 6,9, рис. 35Б,3, 5, 9, 10, 12]):

1 - железный кинжал; 2-3 - железные ножны (?) и нож; 4 - каменный оселок; 5 - золотая серьга;

6 - каменная плитка; 7 - серебряная булавка; 8 - железный «умбон» или украшение колчана

с золотой инкрустацией; 9-10 - железные удила; 11 - железные распределители ремней

Fig. 5. Items from mound 7 of Sara burial ground, the finds of which are not confirmed by the text of D.I. Zakharov's report and illustrations to it (after: [Smirnov, 1964, fig. 35A, 1-3, 5, 6,9, fig. 355,3,5,9, 10, 12]):

$$
\begin{gathered}
1 \text { - iron dagger; } 2-3 \text { - iron scabbard (?) and a knife; } 4-\text { whetstone; } 5 \text { - gold earring; } \\
6 \text { - stone tile; } 7-\text { silver pin; } 8-\text { iron "umbo" or quiver decoration with gold inlay; } \\
9-10-\text { iron bit; } 11 \text { - iron strap distributors }
\end{gathered}
$$




\section{СПИСОК ЛИТЕРАТУРЫ}

Бытковский О. Ф., 2016. К вопросу о географической локализации кургана в урочище Биш-Оба (по данным историографических исследований) // Константин Федорович Смирнов и современные проблемы сарматской археологии : материалы IX Междунар. науч. конф. «Проблемы сарматской археологии и истории», посвящ. 100-летию со дня рождения К.Ф. Смирнова. Оренбург : Изд-во ОГПУ. C. $43-50$.

Васильев В. Н., Савельев Н. С., Федоров В. К., 1995. Итоги двухлетних совместных работ ИИЯЛ БГОМ // Наследие веков: Охрана и изучение памятников археологии в Башкортостане. Вып. 1. Уфа : М-во культуры Республики Башкортостан. С. 65-84.

Железчиков Б. Ф., 1997. Выверенная база данных по погребальным памятникам савроматской эпохи // Статистическая обработка погребальных памятников Азиатской Сарматии: Вып. II. Раннесарматская культура. М. : ИА РАН. С. 244-277.

Зарецкий И. А., 1929. В Главнауку // Архив ИИМК. Ф. № 2/1929. № 166. Л. 11-11 об.

Захаров Д. И., 1929. Раскопки Д.И. Захаровым кургана близ с. Сары Оренбургского округа. Отчет за 1928 г. и фотографии // Архив ИИМК. Ф. № 2/1929. № 166.

Смирнов К. Ф., 1961. Вооружение савроматов // Материалы и исследования по археологии СССР. Вып. 101. М. : Изд-во АН СССР. 166 с.

Смирнов К. Ф., 1964. Савроматы: Ранняя история и культура сарматов. М. : Наука. 380 с.

Смирнов К. Ф., Петренко В. Г., 1963. Савроматы Поволжья и Южного Приуралья // Свод археологических источников. Вып. Д1-9. М. : Изд-во АН СССР. 40 с., 30 табл.

Ульянов И. В., 2002. Роль огня в погребальной практике ранних ираноязычных кочевников Урало-Поволжья : автореф. дис. ... канд. ист. наук. Ижевск. 26 с.

Rau P., 1929. Die Gräber der frühen Eisenzeit im Unteren Wolgagebiet. Pokrovsk. 112 s.

\section{REFERENCES}

Bytkovskiy O.F., 2016. To the question of geographical localization of barrow in Bish-Oba natural boundary (according to historiographic researches) (According to Historiographic Studies). Konstantin Fyodorovich Smirnov $i$ sovremennye problemy sarmatskoy arkheologii: materialy IX Mezhdunar. nauch. konf. "Problemy sarmatskoy akrheologii $i$ istorii», posvyashh. 100-letiyu so dnya rozhdeniya K.F. Smirnova. Orenburg, OSPU, pp. 43-50. (in Russian).

Vasilyev V.N., Savelyev N.S., Fedorov V.K., 1995. The Results of the Two-Year Joint Work of the IHLL BSUM (the Institute of History, Language and Literature and the Bashkir State United Museum). Nasledie vekov: Okhrana $i$ izuchenie pamyatnikov arkheologii $v$ Bashkortostane, iss. 1. Ufa, Ministry of culture of the Republic of Bashkortostan, pp. 65-84. (in Russian).

Zhelezchikov B.F., 1997. The Verified Database of the Burial Sites of the Sauromatian Era. Statisyical study of funeral antiquities of Asian Sarmatia, vol. II. Early sarmatian culture. Moscow, IA RAS, pp. 244-277. (in Russian).

Zareckiy I.A., 1929. To Glavnauka (the Main Department of Scientific, Scientific and Art and Museum Institutions). Arkhiv IIMK, fond no. 2/1929, no. 166, p. 11 and turnover. (in Russian).

Zakharov D.I., 1929. D.I. Zakharov's Excavations of a Kurgan near the Village Sari in Orenburg District. Arkhiv IIMK, fond no. 2/1929, no. 166. (in Russian).

Smirnov K.F., 1961. Sauromatian Weapons. Materialy i issledovaniya po arkheologii SSSR, iss. 101. Moscow, AS USSR. 160 p. (in Russian).

Smirnov K.F., 1964. The Sauromatians: Early History and Culture of the Sarmats. Moscow, Nauka Publ. 380 p. (in Russian).

Smirnov K.F., Petrenko V.G., 1963. The Sauromatians of the Volga Region and the South Urals. Svod arkheologicheskih istochnikov, iss. Д1-9. Moscow, AS USSR. 40 p., 30 tab. (in Russian).

Ul'yanov I.V., 2002. The Role of Fire in the Funeral Practice of the Early Iranian-Speaking Nomads of the Ural-Volga Region. The Author's Abstract of the Dissertation for the Degree of Candidate of History. Izhevsk. 26 p. (in Russian).

Rau P., 1929. Die Gräber der frühen Eisenzeit im Unteren Wolgagebiet. Pokrovsk. $112 \mathrm{p}$. (in German). 
V.K. Fedorov. Burial Mound 7 of Sara Burial Ground (D.I. Zakharov's Excavations, 1928)

\section{Information about the Author}

Vitaliy K. Fedorov, Candidate of Sciences (History), Deputy Director for Museum Activities, R.G. Kuzeev Institute for Ethnological Studies - Subdivision of the Ufa Federal Research Centre, RAS, Karla Marksa St., 6, 450077 Ufa, Russian Federation, syyri@ yandex.ru, https://orcid.org/0000-00030643-8268

\section{Информация об авторе}

Виталий Кимович Федоров, кандидат исторических наук, заместитель директора по музейной деятельности, Институт этнологических исследований имени Р.Г. Кузеева - обособленное структурное подразделение Уфимского федерального исследовательского центра РАН, ул. Карла Маркса, 6, 450077 г. Уфа, Российская Федерация, syyri@ yandex.ru, https://orcid.org/ 0000-0003-0643-8268 